\title{
The Value of F-18-fluorodeoxyglucose Positron Emission Tomography/Computed Tomography for the Detection of Residual Breast Tumor or Axillary Metastasis after Neoadjuvant Chemotherapy in Invasive Ductal Carcinoma of the Breast
}

\author{
Memenin İnvazif Ductal Karsinomunda 18F- florodeoksiglukoz Pozitron Emisyon \\ Tomografisi/Bilgisayarlı Tomografi'nin Neoadjuvan Kemoterapiden Sonra Kalan \\ Meme Tümörünü ve Aksilla Metastazını Belirlemedeki Değeri
}

(1) Kezban Berberoğlu

Anadolu Medical Center, Department of Nuclear Medicine, Kocaeli, Turkey

\begin{abstract}
Introduction: Accurate evaluation of pathological response after neoadjuvant chemotherapy would aid in treatment and surgical planning as well as prediction of outcomes. This study examined the value of F-18-fluorodeoxyglucose positron emission tomography/computed tomography (F-18-FDG PET/ (T) in predicting pathologically confirmed residual tumor in breast or presence of axillary metastasis when performed after completion of neoadjuvant therapy in patients with invasive ductal carcinoma (IDC) of the breast cancer.
\end{abstract}

Methods: This retrospective study included 52 IDC of the breast who received neoadjuvant chemotherapy and underwent F-18-FDG PET/CT between 2015 and 2019 after completion of neoadjuvant chemotherapy. Diagnostic performance parameters of F-18FDG PET/CT for predicting residual tumor or presence of axillary metastasis were estimated based on histopathological findings.

Results: All patients had IDC. F-18-FDG PET/CT exhibited high specificity for both locations $(89.5 \%$ and $93.8 \%$ and for breast and axilla, respectively). The sensitivity of the method, on the other hand, was low for both locations $(66.7 \%$ and $30.0 \%$ for breast and axilla, respectively), particularly for axilla. Falsenegative rate (i.e., missing rate) for breast and axilla was $9.1 \%$ and $0 \%$ for the tumors $>8 \mathrm{~mm}$ in diameter.

Conclusion: F-18-FDG PET/CT does not seem to provide reliable information on the presence of a residual tumor or node metastasis when performed after the completion of neoadjuvant treatment in IDC of the breast. New diagnostic modalities utilized at different time points or including a combination of different imaging methods are warranted.

Keywords: F-18-fluorodeoxyglucose positron emission tomography/computerized tomography, breast cancer, neoadjuvant chemotherapy, residual tumor, complete response, axillary metastasis, invasive ductal carcinoma

\section{ÖZ}

Amaç: Neoadjuvan kemoterapiden sonra patolojik yanıtın doğru değerlendirilmesi hem cerrahi planlanmasına hem de tedavi sonuçların tahmin edilmesine yardımcı olacaktır. Bu çalışma F-18-fluorodeoksiglukoz pozitron emisyon tomografisi/ bilgisayarlı tomografi'nin (F-18-FDG PET/BT), memenin invazif duktal karsinomu (IDK) olan hastalarda, neoadjuvan tedavinin tamamlanmasından sonra yapıldığında, cerrahi sonrası patolojik olarak doğrulanmıș memede kalan tümörü ve aksillada metastaz varlı̆̆ını tahmin etmedeki değerini incelemiștir.

Yöntemler: Bu retrospektif çalıșmaya 2015 ve 2019 yılları arasında neoadjuvan kemoterapi almış ve kemoterapi sonrasında F-18FDG PET/BT yapılmış 52 memenin IDK'si dahil edilmiştir. F-18FDG PET/BT'nin kalan tümörü ya da aksillada metastaz varlığını tahmin etmek açısından, histopatolojik bulgular esas alınarak, diyagnostik performans parametreleri hesaplanmıştır.

Bulgular: Tüm hastalarda IDK tanısı mevcuttu. F-18-FDG PET/ BT'nin özgüllügü her iki lokasyon için de yüksek bulunmuștur (sırasıyla meme ve aksilla için \%89,5 ve \%93,8). Yöntemin duyarlılığı ise her iki lokasyon için, özellikle de aksilla için düșük idi (sırasıyla, meme ve aksilla için \%66,7 ve \%30,0). Sekiz milimetreden büyük tümörler incelendiğinde ise yanlış negatif oranı (gözden kaçan tümörler) meme için \%9, 1, aksilla için \%0 idi.

Sonuç: F-18-FDG PET/BT memenin IDK'de neoadjuvan tedavinin tamamlanmasından sonra yapıldığında rezidü tümör ya da nodal metastaz varlığını göstermede güvenilir bilgi veriyor gibi görünmemektedir. Değişik zaman noktalarında kullanılacak veya değişik görüntüleme yöntemlerini kombine edecek yeni tanısal yöntemlere gereksinim vardır.

Anahtar Kelimeler: F-18-fluorodeoksiglukoz pozitron emisyon tomografisi/bilgisayarlı tomografi, meme kanseri, neoadjuvan kemoterapi, rezidü tümör, tam yanıt, aksilla metastazı, invazif duktal karsinom
Address for Correspondence/Yazıșma Adresi: Kezban Berberoğlu MD, Anadolu Medical Center, Department of Nuclear Medicine, Kocaeli, Turkey

Phone: +90 5325846256 E-mail: kezbanberberoglu@hotmail.com ORCID ID: orcid.org/0000-0002-1796-3239

Cite this article as/Atıf: Berberoğlu K. The Value of F-18-fluorodeoxyglucose Positron Emission Tomography/ Computed Tomography for the Detection of Residual Breast Tumor or Axillary Metastasis after Neoadjuvant Chemotherapy in Invasive Ductal Carcinoma of the Breast.. İstanbul Med J 2020; 21(1): 42-6.

(c) Copyright 2020 by the Istanbul Training and Research Hospital/Istanbul Medical Journal published by Galenos Publishing House.

(C) Telif Hakkı 2020 istanbul Ĕgitim ve Araștırma Hastanesi/Istanbul Tıp Dergisi, Galenos Yayınevi tarafından basılmıștır.
Received/Geliș Tarihi: 12.12 .2019 Accepted/Kabul Tarihi: 06.01.2020 


\section{Introduction}

Breast cancer is the most common malignancy among women in the developed world (1). Advanced diagnostic modalities and new treatment strategies resulted in a decrease in breast cancer-related mortality, although its incidence is on the rise (1). Neoadjuvant therapy is increasingly used for the treatment of patients with breast cancer (2). It helps to downsize the tumor in early breast cancer, thereby increasing chances for breast-conserving surgery (3). Also, it has the potential to convert metastatic lymph nodes to pathologically negative status in a substantial proportion of patients with locally advanced breast cancer (4).

Accurate evaluation of pathological response after neoadjuvant treatment would aid in treatment and surgical planning (5). Correct prediction of the residual tumor site and size would enable successful resection as well as breast tissue preservation as much as possible. Also, it will give an idea of disease prognosis. Several imaging modalities such as magnetic resonance imaging (MRI), positron emission tomography/computerized tomography (PET/CT), ultrasonography, and mammography is currently being used to examine response to neoadjuvant chemotherapy in breast cancer (6). Although widely used, mammography and ultrasonography seems to overestimate tumor volume due to chemotherapy-induced fibrosis and necrosis (7). On the other hand, MRI may overestimate or underestimate the residual tumor in an essential proportion of the patients; thus, it also has some limitations, particularly its inability to discriminate between viable tumor tissue from scar tissue (7). Nevertheless, MRI and F-18-FDG PET/ CT are often used to evaluate response after neoadjuvant chemotherapy for breast cancer $(8,9)$.

F-18-FDG PET/CT provides a quantitative estimation of metabolic changes in the tumor tissue; thus, it has the potential to detect such changes occurring early in the course of chemotherapy (10). Several studies demonstrated the advantage of changes in standardized uptake values in predicting pathological response to neoadjuvant chemotherapy $(11,9,12)$. On the other hand, FDG-PET has been shown to have low sensitivity for small lesions (13). To date, several studies examined the role of $\mathrm{PET} / \mathrm{CT}$ in predicting response to neoadjuvant chemotherapy when performed after the completion of neoadjuvant chemotherapy and before surgery, with inconsistent findings, most of them comparing the findings with that of MRI (6,14-19).

This study aimed to examine the value of 18-FDG PET/CT in predicting pathologically confirmed residual tumor in breast and presence of axillary metastasis when performed after completion of neoadjuvant therapy in patients with invasive ductal carcinoma (IDC) of the breast.

\section{Methods}

\section{Patients}

This retrospectivestudy included 51 female patients(52tumors) diagnosed with IDC of the breast who received neoadjuvant chemotherapy and underwent F-18-FDG PET/CT between the years 2015 and 2019. Patients were eligible for the study if they fulfill the following criteria: Biopsyconfirmed diagnosis of invasive stage IIA, IIB, or IIIA breast carcinoma with no distant metastasis. Patients with inflammatory breast carcinoma, invasive lobular carcinoma, invasive mucinous carcinoma, and patients with distant metastasis were excluded. F-18-FDG-PET/CT was performed 2-3 weeks after the completion of neoadjuvant chemotherapy. Patients were subjected to either breast-conserving surgery or modified radical mastectomy with sentinel node biopsy and/or axillary lymph node dissection after neoadjuvant chemotherapy. The study protocol of this study was approved by the Anadolu Medical Center Local Ethics Committee (decision no: ASM-EK-19/123, date: 11.12.2019). Informed consent was waived since the trial included retrospective data analysis. Data on patient demographics, tumor histology, assessment of tumor by metabolic response on 18F-FDG-PET/CT imaging was collected.

\section{Neoadjuvant Chemotherapy}

Patients received anthracycline-based, taxane-based, or anthracycline and taxane combination neoadjuvant treatment. Selected patients with high hormone receptor positivity and advanced age received only hormone therapy. In patients with HER2 positivity, trastuzumab \pm pertuzumab was added.

\section{8-FDG PET/CT Examination after Neoadjuvant Treatment}

Patients fasted for at least 6 hours, and the blood glucose level had to be $<150 \mathrm{mg} / \mathrm{dL}$. F-18-FDG $(3.7 \mathrm{MBq} / \mathrm{kg}$ ) was administered through the arm opposite to breast tumor using a venous line to prevent extravasation. Imaging started approximately $60 \mathrm{~min}$ after injection and was performed from mid-thigh level to the base of the skull with arms raised. An integrated PET/CT scanner (Discovery 690, GE Healthcare, Wisconsin, USA) was used for imaging. CT data were acquired first (120 kV;20-120 mAs, determined automatically based on attenuation). Only an oral contrast agent was used. PET emission data were acquired in a 3-dimensional mode, with 3 min per bed position, and reconstructed using iterative reconstruction algorithm with $5 \mathrm{~mm}$ slice thickness. Attenuation-corrected images were normalized for injected dose and body weight, and subsequently converted into SUV, defined as: [tracer concentration $(\mathrm{kBq} / \mathrm{mL})$ ] / [injected activity $(\mathrm{kBq}) /$ patient body weight $(\mathrm{g})$. The 3D volume of interest was automatically drawn around the primary tumor and around the axillary lymph nodes, when present.

\section{Postoperative Pathological Examination}

All cases were diagnosed by tru-cut biopsy. Estrogen receptor and progesterone receptor positivity, the grade of differentiation, and Ki-67 were determined by immunohistochemical (IHC) staining. HER-2 status was accepted as "positive" if strong (3+) membranous staining was seen on IHC. Fluorescence in situ hybridization analysis (FISH) was done in samples with moderate $(2+)$ membranous staining on IHC, and HER2 status was accepted as "positive" if FISH showed amplification. All postoperative specimens were microscopically evaluated to identify the residual invasive tumor. $\mathrm{pCR}$ was defined as no residual invasive tumor cells in the breast or axillary nodes. Pathological responses other than pCR were defined as incomplete response (non-pCR).

\section{Assessment of Metabolic Response}

Regions of interest were identified and outlined for both primary tumor and axillary lymph node areas, and SUV values were calculated. 
Adjacent breast or axillary tissue without activity was identified, and SUV values were calculated to serve as a background activity. When SUV value for the region of interest is two times or more of background activity, the activity in the region of interest was considered pathological and evidence for residual tumor/metastasis.

\section{Statistical Analysis}

Statistical analyses were performed using SPSS software for Windows (Version 21.0; SPSS Inc., New York, New York, USA). Descriptive data were presented as mean \pm standard deviation or number (frequency), where appropriate. The sensitivity and specificity of the F-18-FDG PET/CT examination following the completion of neoadjuvant chemotherapy were calculated for the diagnosis of histologically confirmed residual tumor in axilla or breast.

\section{Results}

Table 1 shows patient and tumor characteristics. All patients were female and diagnosed with IDC of the breast. Half of the patients received neoadjuvant treatment with anthracycline and taxane combination, whereas $13.5 \%$ and $32.7 \%$ of them received anthracycline-based and taxane-based neoadjuvant therapy. Only two patients received hormone therapy. Trastuzumab \pm pertuzumab was added in $36.5 \%$ of patients due to HER2 positivity. Postoperative histopathological examination identified residual invasive tumors in the breast in almost two-thirds of the patients (63.5\%). On the other hand, metastasis was present in the axilla in slightly more than one-third of the patients (38.5\%).

Table 2 shows diagnostic parameters for F-18-FDG PET/CT for the detection of residual invasive tumor in breast and metastasis in the axilla. F-18-FDG PET/CT exhibited high specificity for primary tumor and axilla (93.8\% and $89.5 \%$, respectively). The sensitivity of the method, on the other hand, was low for both locations $(66.7 \%$ for primary tumor and $30.0 \%$ for axilla). Around one-quarter of the residual invasive tumors/ metastases were missed at these locations. When only the patients with histologically positive residual invasive tumor/metastasis were analyzed separately ( $n=20$ and 33 for axilla and breast, respectively), a false negative rate (i.e., missing rate) for axilla and breast was $0 \%$ and $9.1 \%$ for the tumors $>8 \mathrm{~mm}$ in diameter. Among 33 residual invasive tumors in the breast, 22 of them were $>8 \mathrm{~mm}(66.7 \%)$; on the other hand, only 4 of 20 axillary metastases were greater than $>8 \mathrm{~mm}(20.0 \%)$.

\section{Discussion}

This study examined the diagnostic value of F-18-FDG PET/CT in predicting residual tumor or presence of axillary metastasis after the completion of neoadjuvant treatment in patients with IDC of the breast. F-18-FDG PET/CT exhibited high sensitivity but low specificity in this setting, with a high false-negative rate; however, its diagnostic value seems better for residual tumors or axillary metastasis $>8 \mathrm{~mm}$.

To date, several other studies examined the diagnostic value of F-18FDG PET/CT in predicting residual tumor after the completion of neoadjuvant therapy; and most studies compared F-18-FDG PET/CT with MRI. Choi et al. (20) compared the performances of PET/CT and MRI for response evaluation after neoadjuvant treatment in breast cancer. Imaging studies were performed before and after neoadjuvant

treatment, and their diagnostic value in predicting complete/partial response (responders) and stable/progressive disease (non-responders) was evaluated based on postoperative pathological findings. PET/CT exhibited lower specificity and accuracy and higher sensitivity when compared to MRI in response evaluation, although these differences between the two methods did not reach statistical significance (20).

A recent study compared two PET methods [ring-type dedicated breast PET (dbPET) vs whole-body PET-CT (WBPET)] for the assessment of residual tumor after neoadjuvant chemotherapy for breast cancer (14). dbPET was more sensitive than WBPET when quantitative methods

Table 1. Patient and tumor characteristics

\begin{tabular}{|c|c|}
\hline Characteristics & $n=52$ \\
\hline Age, y (mean \pm SD) & $48.9 \pm 10.8$ \\
\hline \multicolumn{2}{|l|}{ Tumor receptor characteristics } \\
\hline Estrogen receptor-positive & $34(65.4 \%)$ \\
\hline Progesterone receptor positive & $24(46.2 \%)$ \\
\hline HER2 positive & $19(36.5 \%)$ \\
\hline Triple-negative tumor & $12(23.1 \%)$ \\
\hline Luminal A & $7(13.5 \%)$ \\
\hline Luminal B & $15(28.8 \%)$ \\
\hline \multicolumn{2}{|l|}{ Chemotherapy type } \\
\hline Anthracycline-based & $7(13.5 \%)$ \\
\hline Taxane-based & $17(32.7 \%)$ \\
\hline Anthracycline taxane combined & $26(50.0 \%)$ \\
\hline Hormone & $2(3.8 \%)$ \\
\hline Trastuzumab \pm pertuzumab & $19(36.5 \%)$ \\
\hline \multicolumn{2}{|l|}{ Histological examination } \\
\hline Residual invasive tumor in axilla & $20(38.5 \%)$ \\
\hline Residual invasive tumor in the breast & $33(63.5 \%)$ \\
\hline $\begin{array}{l}\text { Residual invasive tumor diameter in axilla, } \mathrm{mm} \text {, } \\
(\text { mean } \pm \mathrm{SD})^{*}\end{array}$ & $5.8 \pm 5.7$ \\
\hline $\begin{array}{l}\text { Residual invasive tumor diameter in the breast, } \\
\mathrm{mm},(\text { mean } \pm S D)^{*}\end{array}$ & $17.5 \pm 13.0$ \\
\hline \multicolumn{2}{|l|}{ Unless otherwise stated, data presented in $\mathrm{n}(\%)$. } \\
\hline \multicolumn{2}{|c|}{$\begin{array}{l}\text { HER2: human epidermal growth factor receptor } 2 \text {, *: for patients with histologically } \\
\text { positive residual invasive tumor, SD: standard deviation, Luminal A: hormone-receptor } \\
\text { positive (estrogen-receptor and/or progesterone-receptor positive), HER2 negative, } \\
\text { and has Ki- } 67 \leq 14 \text {, Luminal B: hormone-receptor positive (estrogen-receptor and/or } \\
\text { progesterone-receptor positive), and either HER2 positive or HER2 negative, Ki-67 }>14\end{array}$} \\
\hline
\end{tabular}

Table 2. Diagnostic value of F-18-fluorodeoxyglucose positron emission tomography/computed tomography for the detection of residual invasive tumor or presence of axillary metastasis after neoadjuvant chemotherapy

\begin{tabular}{|l|l|l|}
\hline & Primary tumor & Axilla \\
\hline True positive, $\mathrm{n}(\%)$ & $22(42.3 \%)$ & $6(11.5 \%)$ \\
\hline True negative, $\mathrm{n}(\%)$ & $17(32.7 \%)$ & $30(57.7 \%)$ \\
\hline False positive, $\mathrm{n}(\%)$ & $2(3.8 \%)$ & $2(3.8 \%)$ \\
\hline False negative, $\mathrm{n}(\%)$ & $11(21.2 \%)$ & $14(26.9 \%)$ \\
\hline Sensitivity, \% $(95 \% \mathrm{Cl})$ & $66.7(48.2-82.0)$ & $30.0(11.9-54.3)$ \\
\hline Specificity, \% $(95 \% \mathrm{Cl})$ & $89.5(66.9-98.7)$ & $93.8(79.2-99.2)$ \\
\hline Cl: confidence interval & & \\
\hline
\end{tabular}


(84\% vs $26 \%$ ) or qualitative methods (58\% vs $21 \%$ ) were used; however, these figures may still be considered relatively low for the detection of a residual tumor (14).

A recent meta-analysis reviewed the findings of 13 studies comparing $\mathrm{MRI}$ and PET/CT in predicting response after neoadjuvant treatment (15). The pooled sensitivity for PET/CT and MRI was $77 \%$ and $88 \%$, respectively. Corresponding figures for specificity were 88\% (PET/CT) and 69\% (MRI). The authors recommended that MRI might be a more suitable method for predicting pathologic response to neoadjuvant chemotherapy. Another meta-analysis examining the prediction of pathological complete response to neoadjuvant chemotherapy by these two imaging modalities from six studies found a high sensitivity for PET/CT (86\%), and the authors recommended combined use of these modalities for better predicting response to neoadjuvant treatment (16). Another meta-analysis that included ten studies compared the value of MRI and $\mathrm{PET} / \mathrm{CT}$ in predicting pathological response. During the neoadjuvant treatment, the performance of PET/CT was similar to MRI in terms of sensitivity (91\% vs $89 \%$ ) and better in terms of specificity (69\% vs $42 \%$ ). On the other hand, MRI had better performance when either of the two methods was used after the completion of neoadjuvant treatment, with significantly higher sensitivity (88\% vs 57\%) (19). There is a wide range of sensitivity and specificity across studies, which may be attributed to the heterogeneity between studies (17).

Studies examining the value of diagnostic methods in predicting complete axillary response after neoadjuvant therapy for breast cancer are relatively few. A study by Vicente et al. (21) examined the predictive value of 18-FDG PET/CT for axillary lymph node response after neoadjuvant chemotherapy performed at different time points: before, during, and after neoadjuvant therapy. Predictive values of axillary response were low for both early and late evaluation (sensitivity, 52\% vs $32 \%$ ), in line with the findings of the present study. A systematic review included four studies with a relatively small sample. The reported positive predictive value (PPV) for complete axillary response ranged between $40 \%$ and $100 \%$ for different diagnostic methods. Among the studies included in the review, in the study by Hieken et al. (18), post neoadjuvant F-18-FDG PET-CT exhibited sensitivity, specificity, PPV, and negative predictive value of $85 \%, 63 \%, 61 \%$, and $86 \%$, respectively. You et al. (6) evaluated the axillary lymph node status after neoadjuvant chemotherapy and compared the diagnostic performances of ultrasound, MRI, and F-18-FDG PET/CT. The sensitivity of ultrasound, $\mathrm{MRI}$, and $\mathrm{PET} / \mathrm{CT}$ was $50 \%, 72 \%$, and $22 \%$, respectively. Corresponding figures for specificity were $77 \%$, 54\%, and $85 \%$, with PET/CT having the highest specificity. On the other hand, a combination of the three methods had the highest sensitivity.

In this study, 18-FDG PET/CT exhibited relatively better performance for predicting tumors/metastases larger than $8 \mathrm{~mm}$. This is in line with the findings of a study that demonstrated low sensitivity of 18-FDG $\mathrm{PET} / \mathrm{CT}$ for small lesions. That study by Kumar et al. (13) examined the clinicopathological factors associated with false-negative FDG-PET in primary breast cancer and found that small tumor size $(\leq 10 \mathrm{~mm})$ and low tumor grade were independent predictors of false-negative results. This may also explain the low sensitivity found in our study, particularly for axillary metastasis. The substantial reduction of the tumor size after neoadjuvant treatment seems to be responsible for this finding. Although sensitivity for detecting an invasive tumor in the breast is somewhat acceptable, sensitivity for detecting axillary metastases, in particular, is substantially low; probably, since only one-fifth of axillary metastases were $>8 \mathrm{~mm}$ whereas, two-thirds of residual invasive tumors in the breast had such a great size.

This study has several limitations. Firstly, the sample size is relatively small for examining clinicopathological factors that may affect the predictive performance of $\mathrm{PET} / \mathrm{CT}$. Another limitation is that not all patients were node-positive at baseline before neoadjuvant treatment. Thus, any metastasis in axilla may not necessarily be considered residual after neoadjuvant therapy.

\section{Conclusion}

F-18-FDG PET/CT alone does not seem to provide reliable information on the presence of a residual tumor or node metastasis when performed after the completion of neoadjuvant treatment in IDC of the breast. Considering that preoperative restaging is essential in terms of treatment planning and outcome prediction, new diagnostic modalities utilized at different time points or including a combination of different imaging methods are warranted to predict response to neoadjuvant chemotherapy better.

Ethics Committee Approval: The study protocol of this study was approved by the Anadolu Medical Center Local Ethics Committee (decision no: ASM-EK-19/123, date: 11.12.2019).

Informed Consent: Informed consent was waived since the trial included retrospective data analysis. Data on patient demographics, tumor histology, assessment of tumor by metabolic response on 18F-FDG-PET/CT imaging was collected.

Peer-review: Externally peer-reviewed.

Financial Disclosure: The authors declared that this study received no financial support.

\section{References}

1. Ferlay J, Steliarova-Foucher E, Lortet-Tieulent J, Rosso S, Coebergh JW, Comber $\mathrm{H}$, et al. Cancer incidence and mortality patterns in Europe: estimates for 40 countries in 2012. Eur J Cancer 2013; 49: 1374-403.

2. Kaufmann M, von Minckwitz G, Mamounas EP, Cameron D, Carey LA, Cristofanilli $\mathrm{M}$, et al. Recommendations from an international consensus conference on the current status and future of neoadjuvant systemic therapy in primary breast cancer. Ann Surg Oncol 2012; 19: 1508-16.

3. Man VC, Cheung PS. Neoadjuvant chemotherapy increases rates of breastconserving surgery in early operable breast cancer. Hong Kong Med J 2017; 23: $251-7$.

4. Rouzier R, Extra JM, Klijanienko J, Falcou MC, Asselain B, Vincent-Salomon A, et al. Incidence and prognostic significance of complete axillary downstaging after primary chemotherapy in breast cancer patients with T1 to T3 tumors and cytologically proven axillary metastatic lymph nodes. J Clin Oncol 2002; 20: $1304-10$

5. Thomas E, Holmes FA, Smith TL, Buzdar AU, Frye DK, Fraschini G, et al. The use of alternate, non-cross-resistant adjuvant chemotherapy on the basis of pathologic response to a neoadjuvant doxorubicin-based regimen in women 
with operable breast cancer: long-term results from a prospective randomized trial. J Clin Oncol 2004; 22: 2294-302.

6. You S, Kang DK, Jung YS, An YS, Jeon GS, Kim TH. Evaluation of lymph node status after neoadjuvant chemotherapy in breast cancer patients: Comparison of diagnostic performance of ultrasound, MRI and (1)(8)F-FDG PET/CT. Br J Radiol 2015; 88: 20150143.

7. Yeh E, Slanetz P, Kopans DB, Rafferty E, Georgian-Smith D, Moy L, et al. Prospective comparison of mammography, sonography, and MRI in patients undergoing neoadjuvant chemotherapy for palpable breast cancer. AJR Am J Roentgenol 2005; 184: 868-77.

8. Shin HJ, Baek HM, Ahn JH, Baek S, Kim H, Cha JH, et al. Prediction of pathologic response to neoadjuvant chemotherapy in patients with breast cancer using diffusion-weighted imaging and MRS. NMR Biomed 2012; 25: 1349-59.

9. Humbert O, Cochet A, Coudert B, Berriolo-Riedinger A, Kanoun S, Brunotte F, et al. Role of positron emission tomography for the monitoring of response to therapy in breast cancer. Oncologist 2015; 20: 94-104.

10. Tateishi U, Miyake M, Nagaoka T, Terauchi T, Kubota K, Kinoshita T, et al. Neoadjuvant chemotherapy in breast cancer: Prediction of pathologic response with PET/CT and dynamic contrast-enhanced MR imagingprospective assessment. Radiology 2012; 263: 53-63.

11. Cheng X, LiY, Liu B, XU Z, Bao L, Wang J. 18F-FDG PET/CT and PET for evaluation of pathological response to neoadjuvant chemotherapy in breast cancer: A meta-analysis. Acta Radiol 2012; 53: 615-27.

12. Choi JH, Lim HI, Lee SK, Kim WW, Kim SM, Cho E, et al. The role of PET CT to evaluate the response to neoadjuvant chemotherapy in advanced breast cancer: Comparison with ultrasonography and magnetic resonance imaging. J Surg Oncol 2010; 102: 392-7.

13. Kumar R, Chauhan A, Zhuang H, Chandra P, Schnall M, Alavi A. Clinicopathologic factors associated with false negative FDG-PET in primary breast cancer. Breast Cancer Res Treat 2006; 98: 267-74.
14. Koyasu H, Goshima S, Noda Y, Nishibori H, Takeuchi M, Matsunaga K, et al. The feasibility of dedicated breast PET for the assessment of residual tumor after neoadjuvant chemotherapy. Jpn J Radiol 2019; 37: 81-7.

15. Li H, Yao L, Jin P, Hu L, Li X, Guo T, et al. MRI and PET/CT for evaluation of the pathological response to neoadjuvant chemotherapy in breast cancer: A systematic review and meta-analysis. Breast 2018; 40: 106-15.

16. Liu Q, Wang C, Li P, Liu J, Huang G, Song S. The Role of (18)F-FDG PET/CT and MRI in Assessing Pathological Complete Response to Neoadjuvant Chemotherapy in Patients with Breast Cancer: A Systematic Review and MetaAnalysis. Biomed Res Int 2016; 2016: 3746232.

17. Paydary K, Seraj SM, Zadeh MZ, Emamzadehfard S, Shamchi SP, Gholami S, et al. The Evolving Role of FDG-PET/CT in the Diagnosis, Staging, and Treatment of Breast Cancer. Mol Imaging Biol 2019; 21: 1-10.

18. Hieken TJ, Boughey JC, Jones KN, Shah SS, Glazebrook KN. Imaging response and residual metastatic axillary lymph node disease after neoadjuvant chemotherapy for primary breast cancer. Ann Surg Oncol 2013; 20: 3199-204.

19. Sheikhbahaei S, Trahan TJ, Xiao J, Taghipour M, Mena E, Connolly RM, et al. FDG-PET/CT and MRI for evaluation of pathologic response to neoadjuvant chemotherapy in patients with breast cancer: A meta-analysis of diagnostic accuracy studies. Oncologist 2016; 21: 931-9.

20. Choi EK, Yoo IR, Kim SH, Park SY, O JH, Kang BJ. The value of pre- and post-neoadjuvant chemotherapy F-18 FDG PET/CT scans in breast cancer: Comparison with MRI. Acta Radiol 2018; 59: 41-9.

21. Garcia Vicente AM, Soriano Castrejon A, Leon Martin A, Relea Calatayud F, Munoz Sanchez Mdel M, Cruz Mora MA, et al. Early and delayed prediction of axillary lymph node neoadjuvant response by (18)F-FDG PET/CT in patients with locally advanced breast cancer. Eur J Nucl Med Mol Imaging 2014; 41: 1309-18. 